\title{
Chronology: The European Union in 2012
}

\author{
FABIAN GUY NEUNER
}

University of Michigan

\section{At a Glance}

Presidencies of the EU Council: Denmark (1 January-30 June) and Cyprus (1 July-31 December).

\section{January}

1

1

13

16

17

17

22

23

23

30

30

Denmark takes over the EU Council Presidency.

New Hungarian constitution enters into force.

Rating agency Standard \& Poor's (S\&P) downgrades the credit rating of nine EU Member States, including France and Italy.

S\&P downgrades the credit rating of the European Financial Stability Facility (EFSF) to AA+.

German Socialist MEP Martin Schulz is elected President of the European Parliament.

The European Commission launches infringement proceedings against Hungary over legislation that came into force under the new constitution. Croatians vote in favour of joining the EU in an accession referendum. EU foreign ministers adopt new sanctions against Iran, in the form of an oil embargo, over the country's nuclear programme.

Intergovernmental ministerial meeting reaches agreement on the new European Stability Mechanism (ESM) Treaty and on the draft Fiscal Compact Treaty.

The Erasmus programme celebrates its 25th anniversary.

At a summit in Brussels all EU Member States except the United

Kingdom and the Czech Republic endorse the final version of the Treaty on Stability, Coordination and Governance in the Economic and Monetary Union (Fiscal Compact) and the ratification process begins.
February
2
5
6
8
10
10
12
The new version of the ESM Treaty is signed.
Saul Niinistö is elected president of Finland.
Romanian Prime Minister Emil Boc resigns following protests over austerity measures.
Commission publishes proposals for a 'European Statute for Foundations'. Slovenian parliament confirms Janez Janša's government.
12th EU-India summit in New Delhi.
In a move to secure a second EU/IMF (International Monetary Fund)
bail-out and avert bankruptcy, the Greek parliament passes austerity measures amid popular protests. 
13 Rating agency Moody's downgrades six eurozone members' credit ratings.

14 14th EU-China summit in Beijing.

14 Commission publishes first alert mechanism report on macroeconomic imbalances in the Member States.

17 German President Christian Wulff resigns over corruption claims.

18 Latvians vote against making Russian a second national language in a referendum.

22 Commission proposes suspending €495 million worth of cohesion funds for Hungary over the country's failure to curb its excessive deficit.

Commission requests that the European Court of Justice (ECJ) assesses whether the Anti-Counterfeiting Trade Agreement (ACTA) violates fundamental human rights.

S\&P downgrades Greece's credit rating to 'selective default'. EU withdraws all Member State ambassadors from Belarus after the country had told the ambassadors of the EU and Poland to leave the country following renewed EU sanctions. The European Central Bank (ECB) agrees to provide $€ 530$ billion in low-interest loans to banks across the Member States. Commission proposes central securities depositories regulation.

March

European Council. Discussion centred on the implementation of EU economic strategy and the completion of the single market. The Treaty on Stability, Coordination and Governance in the Economic and Monetary Union (Fiscal Compact) was signed. Further, Serbia was granted candidate status and Herman Van Rompuy was re-elected as the Council's President.

$4 \quad$ Vladimir Putin is elected president of Russia.

10 Robert Fico's Smer Social Democracy Party wins an absolute majority of seats in the parliamentary election in Slovakia.

13 Council adopts a decision to suspend €495.2 million in cohesion funds for Hungary due to the country taking insufficient steps to correct its budget deficit.

13 Eurozone finance ministers approve second Greek bail-out deal worth $€ 130$ billion.

16 Nicolae Timofti, an independent, is elected president of Moldova by a parliamentary vote.

18 Joachim Gauck is elected president of Germany in an indirect election.

First day for the submission of proposals through the European citizens' initiative (ECI).

2 President of Hungary Pál Schmitt resigns over a plagiarism scandal.

16 EU 'Sustainable Energy for All' summit in Brussels.

18 Commission adopts a communication on growth and jobs for Greece. 
23 Dutch Prime Minister Mark Rutte announces the resignation of his coalition government after no agreement was reached on austerity measures.

25 Commission presents its proposal for the EU budget for 2013.

May

June

4

Fidesz Party candidate János Áder is elected president of Hungary in an indirect election.

S\&P upgrades Greece's credit rating to CCC.

François Hollande is elected president of France in the second round, beating incumbent Nicolas Sarkozy.

Parliamentary elections in Serbia. Socialist Party leader Ivica Dačić becomes prime minister heading a coalition with United Serbia and the Party of United Pensioners of Serbia.

Antonis Samaras' New Democracy Party wins a plurality in the Greek legislative elections.

Spain partially nationalizes Bankia group.

Commission officially launches the first ECI to coincide with Europe day.

38th G8 summit in Camp David.

Tomislav Nikolić is elected president of Serbia in a second round run-off election.

The Irish vote in favour of an amendment to the country's constitution to enable ratification of the European Fiscal Compact in a referendum.

Brussels Economic Forum.

Commission starts talks on visa liberalization with Georgia.

Spanish government announces request for financial assistance for up to $€ 100$ billion.

Bujar Nishani is elected president of Albania in the fourth round of an indirect election

Inaugural EU-Iraq framework agreement signed.

The Socialist Party wins an absolute majority in the French legislative elections.

After attempts to form a government following the May elections failed, a new legislative election took place in Greece returning New Democracy as the largest party. 7th G20 summit held in Mexico.

The leaders of Germany, France, Italy and Spain agree to a blueprint for a European growth pact worth $€ 130$ billion. Cyprus becomes the fifth eurozone country to request a bail-out. The European Council approved a 'compact for growth and jobs', and held discussions on the multi-annual financial framework. Moreover, it was decided to open EU accession negotiations with Montenegro. 
The EU completes its police mission in Bosnia and Herzegovina, thereby marking the end of the first mission launched under the European security and defence policy (ESDP) banner.

Cyprus takes over the EU Council Presidency.

The European Parliament rejects the Anti-Counterfeiting Trade Agreement (ACTA).

French President François Hollande announces plans for tax increases, including a 75 per cent top rate of income tax. The ECB cuts interest rates to 0.75 per cent.

Spanish Prime Minister Mariano Rajoy announces $€ 65$ billion in spending cuts.

Commission decides on draft negotiation directives to start dialogue on possible EU-Japan Free Trade Agreement.

26 Ireland returns to financial bond markets for the first time since September 2010.

After having been suspended from office earlier in the month, Romanian President Traian Bãsecu survives a popular referendum on his impeachment.

\section{August

France unilaterally introduces a financial transactions tax (FTT). Commission, ECB and IMF monitoring visit to Greece to discuss the country's economic recovery.

Commission announces that Europe and Australia will be linking their emissions trading systems.

September

6
ECB President Mario Monti announces unlimited bond buying in the secondary market as a means of regaining control over the spreads between government bond interest rates in the eurozone.

The International Civilian Office (ICO), monitoring the implementation of the Ahtisaari plan in Kosovo, ceases to exist after it determined that Kosovo had fulfilled the obligations laid out in the plan.

The Commission and the Organisation for Economic Co-operation and Development (OECD) publish the 2012 'Education at a Glance' report.

Commission President José Manuel Barroso gives his State of the Union address.

Commission proposes new single supervisory mechanism (SSM), which would enhance supervisory role of the ECB.

German Constitutional Court rules that the ESM does not contravene the country's constitution. 
12 Mark Rutte's People's Party for Freedom and Democracy wins a plurality in the Dutch general election. In November, Rutte becomes prime minister after entering into coalition with the Labour Party.

18 EU-South Africa summit.

20 15th EU-China summit.

27 Germany ratifies the ESM Treaty, thereby ensuring that the ratification threshold is surpassed and the treaty can enter into force.

October

1

2

8

9

10

14

$14 / 28$

16

$18-19$

20

28

Bidzina Ivanishvili's Georgian Dream coalition wins a majority of seats in the Georgian parliamentary election.

The Liikanen Report of the European Commission's High-level Expert

Group on Bank Structural Reform is published. It recommends

strengthening governance and control of banks and separation of activities.

ESM commences operations with its inaugural meeting.

Koen Lenaerts is elected Vice-President of the ECJ.

Commission enlargement progress reports are published. It is recommended that Albania be granted candidate status.

Milo Đukanović's Coalition for a European Montenegro wins the plurality of votes in the Montenegrin parliamentary election.

Lithuanian parliamentary election sees the Social Democratic Party win a plurality of seats.

European Commissioner for Health and Consumer Policy John Dalli resigns following an anti-fraud investigation.

European Council discussions centre on economic recovery, the situation in Greece and EMU governance. Further, the Council discusses relations with strategic partners.

Voters in Iceland approve six proposals in a non-binding constitutional referendum.

Prime Minister Mykola Azarov's Pro-Presidential Party of the Regions wins a plurality of the vote in the Ukrainian parliamentary elections.

November

5-6

7

9th Asia-Europe meeting.

EU-EIB (European Investment Bank) project bond initiative launched.

Greek parliament approves another austerity package worth €13.5 billion.

Croatian Generals Mladen Markač and Ante Gotovina are acquitted by the International Criminal Tribunal for the Former Yugoslavia (ICTY).

Special European Council in order to reach agreement on the terms of the multi-annual financial framework.

27 Eurozone finance ministers and the IMF reach a deal on Greek bail-out.

28 Commission publishes 'Blueprint for a deep and genuine economic and monetary union'.

29-30 2nd European Gender summit. 
December

Borut Pahor is elected president of Slovenia in the second round of a run-off (direct) election.

5 Commission antitrust regulators fine several electronic companies $€ 1.47$ billion over two decade-long cartels.

$5 \quad$ Fourth EU-US Energy Council in Brussels.

9 The Social Liberal Union Party of Prime Minister Victor Ponta wins an absolute majority of seats in both chambers in the Romanian legislative elections.

10 The EU receives the 2012 Nobel Peace Prize.

12 The EP adopts a uniform patent system.

12 The EP awards the 2012 Sakharov Prize to two Iranian activists.

13-14 The European Council agrees a road map for the completion of EMU through deeper integration, and launches the 2013 European Semester.

18 S\&P upgrades Greece's credit rating and sets its outlook to stable.

20 Commission withdraws ACTA referral to ECJ.

20-21 30th EU-Russia summit in Brussels.

21 Italian Prime Minister Mario Monti announces his resignation after the country's parliament passed the budget for the following year. 